TITLE:

\title{
How social relationships of female giraffe (Giraffa camelopardalis tippelskirchi) change after calving
}

$\operatorname{AUTHOR}(S):$

Saito, Miho; Idani, Gen'ichi

\section{CITATION:}

Saito, Miho ... [et al]. How social relationships of female giraffe (Giraffa camelopardalis tippelskirchi) change after calving. African Journal of Ecology 2016, 54(2): 242-244

ISSUE DATE:

2016-06

URL:

http://hdl.handle.net/2433/203012

\section{RIGHT:}

This is the peer reviewed version of the following article: 'African Journal of Ecology', which has been published in final form at http://dx.doi.org/10.1111/aje.12268. This article may be used for non-commercial purposes in accordance with Wiley Terms and Conditions for Self-Archiving:; The full-text file will be made open to the public on 5 MAY 2017 in accordance with publisher's 'Terms and Conditions for Self-Archiving'.; This is not the published version. Please cite only the published version.; この論文は出版社版でありません。引用の際には出版社版をご確認ご利用ください。 
How social relationships of female giraffe (Giraffa camelopardalis tippelskirchi) change after calving

Miho Saito and Gen'ichi Idani

Wildlife Research Center of Kyoto University, 2-24 Tanaka-Sekiden-cho, Sakyo, Kyoto, 606-8203, Japan (Miho Saito and Gen'ichi Idani) 


\section{Introduction}

Giraffe (Giraffa camelopardalis) social structure is described as a fission-fusion society (Bercovitch \& Berry, 2009; Shorrocks \& Croft, 2009), wherein mother-daughter pairs and specific adult female dyads form strong, continuous social relationships (Carter et al. 2013; Bercovitch \& Berry, 2013). Bercovitch and Berry (2013) found that, in addition to related individuals, peers are more likely to establish herds than non-peers. These non-kin relationships may be formed at an early stage through shared membership in a crèche (Carter et al. 2013). However, systematic studies of the ways in which female giraffe social relationships change after giving birth are absent from the literature.

Here, we present observations that contribute towards filling this knowledge gap.

\section{Material and methods}

Our study was conducted in Katavi National Park (Tanzania) in the following time periods: July-November 2010, August-October 2011. Data were usually collected in the daylight hours between 07:30 and 18:30. When a giraffe herd was encountered, herd size was recorded. "Herds" were recognized as groups of giraffe individuals within sight of an observer and engaged in the same activities. We recorded the age-sex classes of all herd members. Age estimates were based on body size, colour, and the shapes of the ossicones. Individuals were classified into four age-sex classes: calf (estimated height below $2.5 \mathrm{~m}$ ), juveniles (estimated height between $2.5 \mathrm{~m}$ and $3.5 \mathrm{~m}$ ), adult female and adult male (estimated height of over $3.5 \mathrm{~m}$ ). Pelage patterns on the necks were used for individual identification. As giraffe mothers suckle only their own calves (Langman, 1977; Pratt \& Anderson, 1979), mother-calf pairs were identified by suckling observations. 
To determine the strength of social associations, we calculated the dyadic association index (DAI; Martin and Bateson, 1993) for all individuals observed more than five times:

$$
\mathrm{DAI}_{A B}=\sum A B /\left(\sum A+\sum B+\sum A B\right)
$$

where $A$ is the number of observations of individual $\mathrm{A}$ is seen without $\mathrm{B} ; B$ is the number of observations of individual $\mathrm{B}$ is seen without $\mathrm{A}$; and $A B$ is the number of observations made when giraffe A and B were in the same herd.

\section{Results and discussion}

Table 1 summarises the number of identified individuals and the numbers of individuals used in the DAI calculations. We were able to identify all mother-calf pairs in both years.

\begin{tabular}{cccccc}
\hline & \multicolumn{5}{c}{ Number of identified individuals } \\
\cline { 2 - 6 } Year & Calf & Juvenile & Female & Male & Total \\
\hline $2010(*)$ & $7(2)$ & $15(4)$ & $23(8)$ & $18(7)$ & $63(21)$ \\
$2011(*)$ & $3(3)$ & $5(3)$ & $17(11)$ & $16(5)$ & $41(22)$ \\
\hline
\end{tabular}

Table 1. Summary of the number of identified individuals

* Number of individuals used in the DAI analysis

Among females observed in 2010, three individuals (A, B, and C) gave birth in 2011. The DAI values of these females differed between 2010 and 2011 (Fig.1); The average DAI values of these three females before the birth of their calves and the average DAI values of the same females after the birth of their calves increased threefold $(0.09 \pm$ $0.06 \rightarrow 0.27 \pm 0.001)$. This suggests that the presence of calves changes the relationships between the mothers. A similar strengthening of female pairs after birth also occurs in 
sperm whale (Physeter macrocephalus) societies, in which communal care of calves seems to augment female social relationships (Gero et al. 2013).
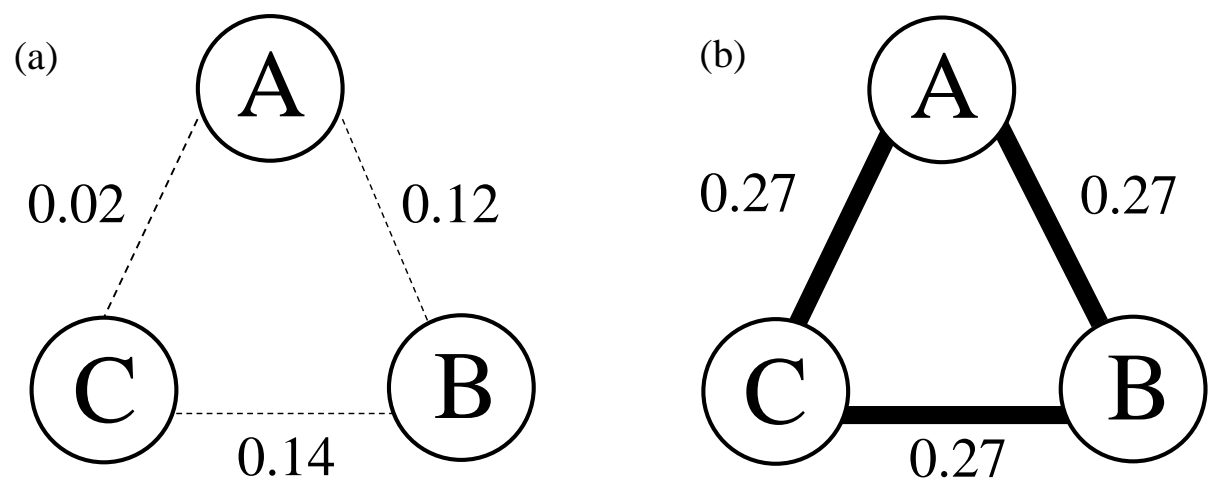

Fig 1. DAI values among the three females; A, B and C

(a) The values for 2010 prior to giving birth (b) The values of 2011 after giving birth

In some areas, about half of giraffe calves are killed by lions (Dagg, 2014). The strengthening of social relationships between female giraffe during the nursery period might help reduce calf predation by way of sharing calf care responsibilities whilst also enabling females to browse at remote locations which is also the case in elk (Cervus elaphus) (Paquet \& Brook, 2004). Therefore, such a tactic could reduce the successful hunting rate of predators.

Giraffe are birth 'hiders'; this is a reproductive strategy in which newborn animals are hidden together in a crèche while mothers leave to browse and drink (Langman, 1977; Pratt \& Anderson, 1979). By remaining hidden while their mothers forage, calves are also able to conserve energy and body water (Langman, 1977). Calves were more frequently observed with peers of the same age than with their mothers because they spent more time with their peers during the daylight hours, especially during the nursery period (table 2). A 
more comprehensive understanding of these relationships will emerge when studies are extended into the hours of darkness when lions, which are the major predators of giraffe (Pratt \& Anderson, 1979), are most active (Schaller, 1972). It is possible that the structure of social relationships may differ during the night to that which we observed during the day if mothers stay close to their calves to ward off predators.

\begin{tabular}{lll}
\hline & \multicolumn{2}{l}{ DAI value $($ mean \pm SD) } \\
\hline Males & $0.05 \pm 0.05$, & $\mathrm{n}=21$ \\
Male-Female & $0.07 \pm 0.06, \quad \mathrm{n}=77$ \\
Male-Juvenile & $0.09 \pm 0.07, \quad \mathrm{n}=21$ \\
Male-Calf & $0.08 \pm 0.06, \quad \mathrm{n}=21$ \\
Females & $0.10 \pm 0.07, \quad \mathrm{n}=55$ \\
Female-Juvenile & $0.12 \pm 0.06, \quad \mathrm{n}=33$ \\
Female-Calf & $0.15 \pm 0.11, \quad \mathrm{n}=33$ \\
Juveniles & $0.11 \pm 0.06, \quad \mathrm{n}=3$ \\
Juvenile-Calf & $0.15 \pm 0.06, \quad \mathrm{n}=9$ \\
Calves & $0.35 \pm 0.01$, & $\mathrm{n}=3$ \\
Mothers & $0.27 \pm 0.001$, & $\mathrm{n}=4$ \\
Mother-Calf & $0.32 \pm 0.02$, & $\mathrm{n}=3$ \\
Calve-Mother & $0.31 \pm 0.05$, & $\mathrm{n}=3$ \\
of the calves' peers & & \\
\hline
\end{tabular}

Table 2. The mean DAI value of each age-sex class combination in 2011

The results for mother-calf dyads were limited to three pairs of giraffe, thus additional data on other mother-calf pairs are needed to confirm the generality of our conclusions. Furthermore, observations on identified individuals should be made during the night and over a longer period to expand our understanding of strong and enduring associations formed during the nursery period.

\section{Acknowledgements}


We thank Japan Society For The Promotion Of Science, COSTECH, TAWIRI, TANAPA and people of the Katavi National Park for their support. 


\section{References}

BERCOVITCH, F.B. \& BERRY, S.M. (2009) Reproductive life history of Thornicroft's giraffe in Zambia. Afr. J. Eco. 48 (2), 535-538.

BERCOVITCH, F.B. \& BERRY, P.S. (2013) Age proximity influences herd composition in wild giraffe. J. Zool. 290, 281-286.

CARTER, D.K., SEDDON, M.J., FRERE, H.C., CARTER, K.J. \& GOLDIZEN, W.A. (2013) Fission-fusion dynamics in wild giraffes may be driven by kinship, spatial overlap and individual social preferences. Anim. Behav. 85, 385-394.

DAGG, A.I. (2014) Giraffe: Biology, Behavior and Conservation. Cambridge University Press, Cambridge.

GERO, S., GORDON, J., \& WHITEHEAD, H. (2013) Calves as social hubs: dynamics of the social network within sperm whale units. Proc. Roy. Soc. Lond., B. 280, 20131113.

LANGMAN, V.A. (1977) Cow-calf relationships in Giraffe (Giraffa camelopardalis giraffe). Z. Tierpsychol. 43, 264-286.

MARTIN, P. \& BATESON, P. (1993) Measuring behaviour: an introductory guide. Cambridge University Press, Cambridge.

PAQUET, P.C. \& BROOK, R.K. (2004) From the Field: Island use as an antipredator tactic by parturient elk and nursery herds in Riding Mountain National Park, Manitoba. Wildl. Soc. Bull. 32 (4), 1321-1324.

PRATT, D.M. \& ANDERSON, V.H. (1979) Giraffe cow-calf relationships and social development of the calf in the Serengeti. Z. Tierpsychol. 51, 233-251.

SCHALLER, G. B. (1972) The Serengeti Lion: A Study of Predator-Prey Relations. The university of Chicago press, Chicago.

SHORROCKS, B. \& CROFT, D.P. (2009) Necks and networks: a preliminary study of population structure in the reticulated giraffe (Giraffa camelopardalis reticulate de Winston). Afr. J. Eco. 47, 374-381. 